\title{
THE SPECIFICITY OF KNOWLEDGE MANAGEMENT IN THE FOOD INDUSTRY IN POLAND
}

\author{
Krzysztof Firlej, Dariusz Żmija
}

\section{Introduction}

Knowledge management is presently of specific interest to economists dealing with corporate governance, as over the last four decades they have noted a lack of influence of the traditional factors of competitive advantage due to the growing impact of global processes, diffusion of innovation and the widespread uptake of modern technologies in production processes. Information and knowledge, which are elementary resources for the blossoming of societies functioning on a modern basis, their economies, and most of all companies, are increasingly important for development. Since Poland's accession to the EU, managers of enterprises have attempted to position them on the market, using mostly traditional, pricecost sources of competitive advantage, which can certainly be beneficial in the initial period, but it will not help to build solid foundations of competitiveness in the future. Education and the development of integrated sets of diverse, unique skills, crucially affecting the value for customers (Pierscionek \& Jurek-Stępień, 2006), are considered to be the most important for them. Improving competitiveness should take the inter-relationships and dependencies arising from the implementation of innovative processes, creating organisational aspects of management in the processes of modernization and revitalization of enterprises into account (Firlej, 2012). A knowledge-based economy, which increasingly requires research on the social sciences, for the most part to strengthen the activities of individual entrepreneurs, should be considered as the economy currently in force (Firlej \& Rydz, 2012a).

\section{Overview of Literature}

Economics theorists point out that the global economy is in the age of information and knowledge, which occurred after the agrarian and industrial revolution. A. Toffler defines the current period as the era associated with the emergence of modern technologies using unlimited communication between individuals, which enabled the development of services and the move away from mass production. P. Drucker, who predicted the formation of a new type of society - "knowledge society", and with it the knowledge-based economy, also presented his position. Whatever you call the now emerging social macrostructures (the following terms are interchangeable: the network society, the knowledge society, digital society, post-industrial society), and the fundamental changes taking place concurrently in the economy, it must be noted - that knowledge is centrally located in the place of changes (Firlej \& Żmija, 2014). Knowledge is designed to contribute to the development of the society, improve the competitiveness of the economy, and should also help to achieve better results for companies and an increase in their value. The market economy began to impose new rules of action on farmers and agrifood sector companies, as a result of which economic categories such as: competition, efficiency and profit (Firlej \& Rydz, 2012b) have gained key importance. The chosen area of study in this paper is the enterprises of the food industry, in which the same mechanisms affect competition on the market, as in other sectors of the economy. Unfortunately, the agribusiness sector in Poland, in which the food industry sector plays a major role, is considered by OECD methodology standards as a low-tech sector. However, its functioning is dependent on innovativeness, the introduction of new product and process solutions and modern technologies. Possibilities in the area of obtaining information and access to the world's knowledge strengthens the productive 
potential of the food industry in Poland, as well as is enables the ongoing modernization and restructuring that lead to change. The food industry is characterized by an exceptional, almost unique specificity, which is manifested in dependence on many macro- and microeconomic factors. The implementation of modern technological solutions based on knowledge transfer and diffusion of innovation has become a source of competitiveness of enterprises in the food industry, not only in Poland but also on the international arena. Knowledge plays a special and important role in the development of any industry and it is "information, skills in some area acquired through learning, life experience, etc., as well as a resource for news of the domain and ability to become aware of something" (Słownik, 1996). Managers of food industry companies often wonder how to manage knowledge and innovation in order to make optimal use of their capabilities, as well as create the right conditions for their development. The implementation of these plans can promote the proper use of knowledge that will enable the identification and implementation of necessary innovation, leading to stable development in the long term (Firlej, 2008). Creativity developing innovative processes raises the level of an enterprise's competitiveness. The inter-relationships and dependencies occurring in carrying out the processes of innovation, creating organisational aspects of management in the processes of modernization and revitalization of the operation of enterprises should be considered as necessary to raise the level of that competitiveness.

\section{Factual Material, Purpose and Research Methodology}

Since 2000, the food industry in Poland has experienced a period of prosperity, as with the accession to the European Union in 2004, the barriers for Polish products disappeared, allowing for the export of food and encouraged producers to increase production. As A. Kowalski notes, cold meats, cheeses, fruits and sweets have become products sought after due to their price, which was the result of lower production costs, and lower raw materials as well as increasing the quality level of the product, as the effect of modernizing the food products sector.

Currently, apart from agriculture, the food industry is the primary department agribusiness sector in our country and one of the fastest growing, and its growth rate is dependent on the rate of economic growth (Urban, 2010). In the years 2000-2013 the structure of the economy was changing, as the subsequent transformation of privatization occurred, a majority of the companies were modernized, which resulted in the activation of the promarket behaviour, as well as the maintenance of the high position of the national economy on the international arena (Firlej, 2010).

The agri-food industry is divided into the following sectors (according to the European Classification of Economic Activities introduced in 1991):

1. The processing and preserving of meat and production of meat products;

2. The processing and preserving of fish and fish products;

3. The processing and preserving of fruit and vegetables;

4. The manufacture and animal oils and fats;

5. The manufacture of dairy products;

6. Manufacture of grain mill products, starches and starch products;

7. Manufacture of bakery and farinaceous products;

8. Manufacture of other food products;

9. Manufacture of beverages.

To illustrate the accepted research, the total number of organisational units of the food industry in Poland were taken, meaning a complete list of companies from the REGON [National Business Entity Register] as at 30 October 2012, which, according to the Polish Classification of Economic Activities (PKD 2007) are classified as Section C Manufacturing, Chapter 10 Manufacture of food products, Chapter 11 Manufacture of beverages and Chapter 12 Manufacture of tobacco products.

\section{Subjects and Study Area and Their Characteristics}

A representative sample of entities for the study population was based on a probabilistic (simple random) sampling techniques. Practical analytical tests were performed in the questionnaire survey. By using random sampling techniques its representativeness was provided, which authorized a reference to the conclusions drawn from the research to the entire study population.

Then, the minimum sample size was determined using the following formula (Szreder, 2004): 


$$
n=\frac{z_{\alpha / 2}^{2} \cdot \hat{p} \cdot(1-\hat{p}) \cdot N}{z_{\alpha / 2}^{2} \cdot \hat{p} \cdot(1-\hat{p})+(N-1) \cdot d^{2}}
$$

where:

$z_{\alpha / 2}$ - the value of the random variable $Z$ with standardized normal distribution, for which, $\mathrm{P}\left(|\mathrm{Z}| \leq z_{\alpha / 2}\right)=1-\alpha$

$\hat{p}$ - sample fraction,

$p$ - unknown, estimated fraction in the population,

$N$ - population size,

$d$ - statistical error.

In determining the minimum sample size the initial sampling was dropped and the value maximizing $\hat{p} X(1-\hat{p})$ was adopted for $\hat{p}$. This move ensures that regardless of the actual value of the estimated fraction of the population, the calculated sample size $\mathrm{n}$ will be sufficient, to ensure that estimation of $\hat{p}$ will not be different from $p$ more than $\pm d$. In view of the fact that the maximum of the above result the interval $[0,1]$ is 0.5 , the formula (1) will have the form:

$$
n=\frac{0.25 \cdot z_{\alpha / 2}^{2} \cdot N}{0.25 \cdot z_{\alpha / 2}^{2}+(N-1) \cdot d^{2}}
$$

Also, the maximum error of statistical results was adopted in the range $\pm 5 \%$, and the fact that it will be calculated at a confidence level of 0.9 . With the help of equation (2) the sufficient minimum sample size was determined $(33,662$ business entities - 267 surveyed companies). The probabilistic sample selection technique allowed for the calculation of the 330 companies that were selected for the study, of which 267 sent questionnaire were completed correctly.

The aim of this study was to examine the issue of knowledge management, which turns out to be one of the reinforcing elements improving the competitiveness level of the organisational units of the food industry in Poland. Attempts were made to identify relations between expenditures incurred on knowledge management, and an increase in the competitiveness of these units. The authors of the study sought to verify the following research hypothesis: the transfer of knowledge and its proper consideration of the adaptation to the existing environmental conditions affect permanently increase the competitiveness of enterprises of the food industry in Poland.
Based on the conducted research, we sought to determine the extent to which knowledge, information and their quality are useful in achieving success by food business operators, what are significant factors reinforcing success, how successful the market is strengthened by its technology and modern information technology, where is positioned intellectual capital and corporate actions when it comes to generating competitive food businesses, as well as management culture, organisational climate, and the value of social responsibility.

The initial task for the extensive research on the issues of knowledge management in the food industry enterprises in Poland were analyses of food companies listed on the Warsaw Stock Exchange WIG Food Sub-index carried out in 2007. Then the opportunities and strengths of knowledge management in the studied companies were verified, and research showed that:

- Knowledge, information, and their quality and timeliness are reinforcing factors for a business' success, which is expressed in increasing their competitiveness and better market position.

- The use of information technology in the current functioning of the company assists in the use qualifications and skills in a structured way, and to manage the capital held.

- The value of the company, high positioned intellectual capital and corporate actions (due to its well designed and functioning system of corporate governance can ensure the targeted prospects for the development of the capital market, which will translate into the development of the whole economy).

- In building a competitive firm, managing the organisational culture and climate, and high social responsibility role of the organisation should be deemed as essential (Firlej, 2008).

On the other hand, a study conducted in 2012 and 2013 year on a select group of 267 food businesses related to the verification of such issues as:

- Knowledge of the company, indicating its sources used.

- Determination of the suitability of activities that support the acquisition and transfer of knowledge which is or have been implemented in companies in the last 5 years. 
- An indication of the systems and tools are used in companies, which are raising the effectiveness of management expertise.

- Clarification of whether the company has a strategy of development in the form of a document and whether issues related to knowledge management are determined in it.

- Verification if the company incurred investments in the last 5 years related to the implementation of knowledge management elements.

- Evaluation of the effects that enterprise knowledge management brings.

- Determination of the level of funding allocated by the company for knowledge management in the following years.

- Indication of whether knowledge management has helped to improve the economic performance of the enterprise.

- Examination whether knowledge management has contributed to the increase in the value of sales of the company.

- Examination whether knowledge management has contributed to the increase in turnover of the company.
- Examination whether knowledge management has contributed to the expansion of markets.

The study began by identifying the economic situation in which the food businesses found themselves in the period from 2007-2012. In the analysed period, the companies operating in the food industry skilfully used the possibility of obtaining funds from the EU structural funds. Businesses had a range of Operational Programmes at their disposal, the most important of which included: 5 national Operational Programmes - Infrastructure and Environment, Innovative Economy, Human Capital, Development of Eastern Poland, Technical Assistance; 16 Regional Operational Programmes; European Regional Cooperation programmes. The great advantage was the ability to take advantage of CIT exemptions (rate 19\%), as well as the availability of favourable conditions in terms of doing business in the Special Economic Zones in separate regions of Poland. Businesses take advantage of income tax exemptions, which amount to about $30-50 \%$ of their investment, or

\section{Fig. 1: Location of surveyed companies in $\%$ according to the size of the population}

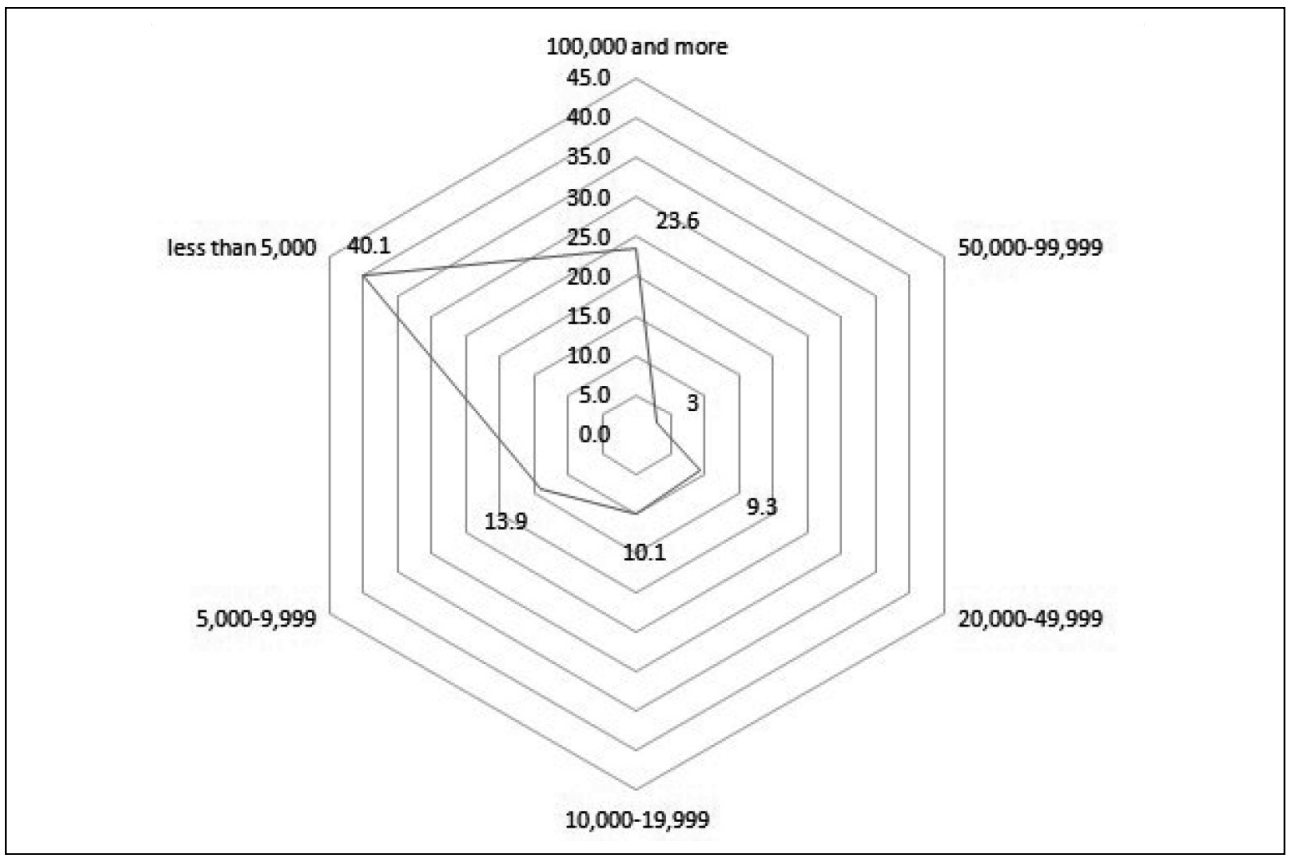

Source: own study based on research 
the two-year employment costs - depending on which is higher. In addition, they also apply for the exemption from property tax, which is often used by the new entrepreneurs.

Presenting the surveyed companies it was calculated that most of them have operated on the market for more than 20 years $(30.7 \%)$, $20.2 \%$ functioned in the ranges of $11-15$ years and $16-20$ years, $16.1 \%$ functioned in the range of $6-10$ years and $12.7 \%$ in the range of $0-5$ years. The study involved $65 \%$ of companies, in which had headquarters in the city and $35 \%$ in rural areas. Interesting results were obtained by asking about the size of the place in which the company operates, since most of them were located in the smallest towns with a population of less than 5 thousand residents $(40.1 \%)$ and in cities with a population of 100,000 and above $(23.6 \%)$. This represented a total of $63.7 \%$, which is almost $2 / 3$ of the total population, and the remaining $1 / 3(26.3 \%)$ was comprised of companies from towns with a population between 5 thousand to 99,000 residents (Fig. 1). The present study also determined the activity or hypothetical market for businesses. It should be noted that respondents themselves determined the extent of their company's activities, which was to obtain information on the existing market, as well as comment on the possibility of obtaining new markets. The results obtained showed that the largest number of companies situate their activities in the region $(28.8 \%)$, followed by the country $(22.1 \%)$, the poviats $(18.7 \%)$ and municipalities (16.5\%). Unfortunately, only $13.9 \%$ of respondents indicated that their company's activities are on international markets (Fig. 2).

The ownership structure of the surveyed enterprises (Fig. 4), in which the private domestic enterprises occupied the dominant position (87.6\%) and foreign private property $(7.5 \%)$ was very interesting.

Property belonging to the cities and villages $(3.4 \%)$, the State Treasury $(0.7 \%)$ and other $(0.7 \%)$ can be treated as an insignificant part of market. This type of business structure formation indicates very strong privatization of food industry enterprises, which in the new reality of the EU have chosen a clear path directed to submit to the generally applicable mechanisms of the free market. The period of our country's membership in the EU structures favoured the privatization particularly of small and medium-sized enterprises in the agri-food sector, which provided them with the normal functioning on the market and the emergence of new opportunities in capital inflows, and above all the use of the financial resources of the European Union structural funds.

In the studied period the legal form of companies also changed. The changes were more favourable for them and more adequate to

\section{Fig. 2: Declared market area}

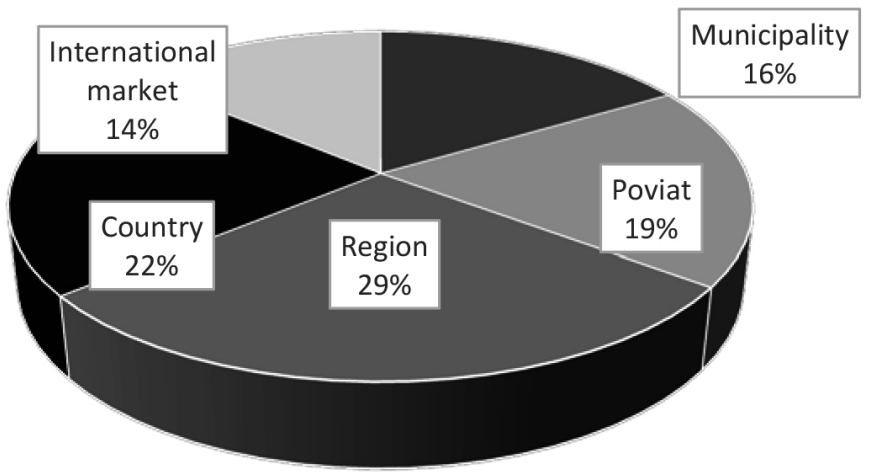

- Municipality - Poviat - Region - Country $=$ International market 


\section{Ekonomika a management}

\section{Fig. 3: Declared ownership structure}

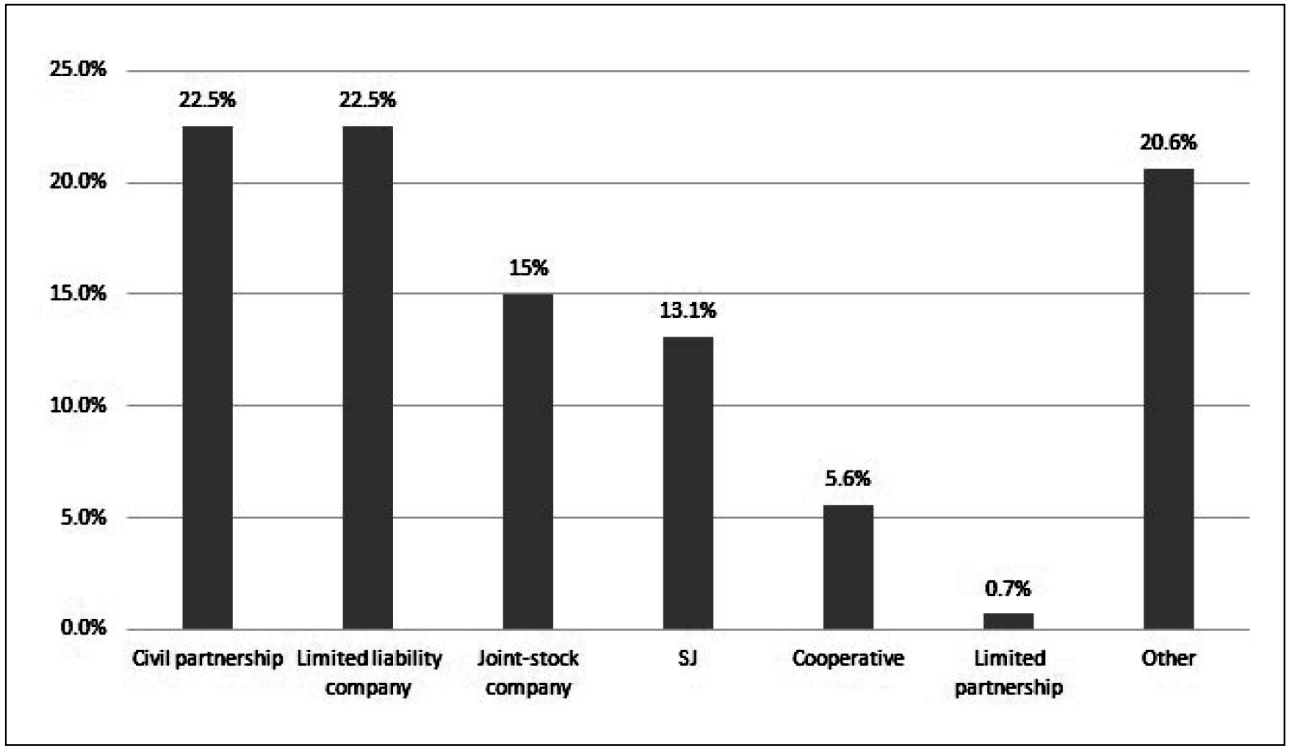

Source: own study based on research

\section{Fig. 4:}

\section{Branches of studied enterprises}

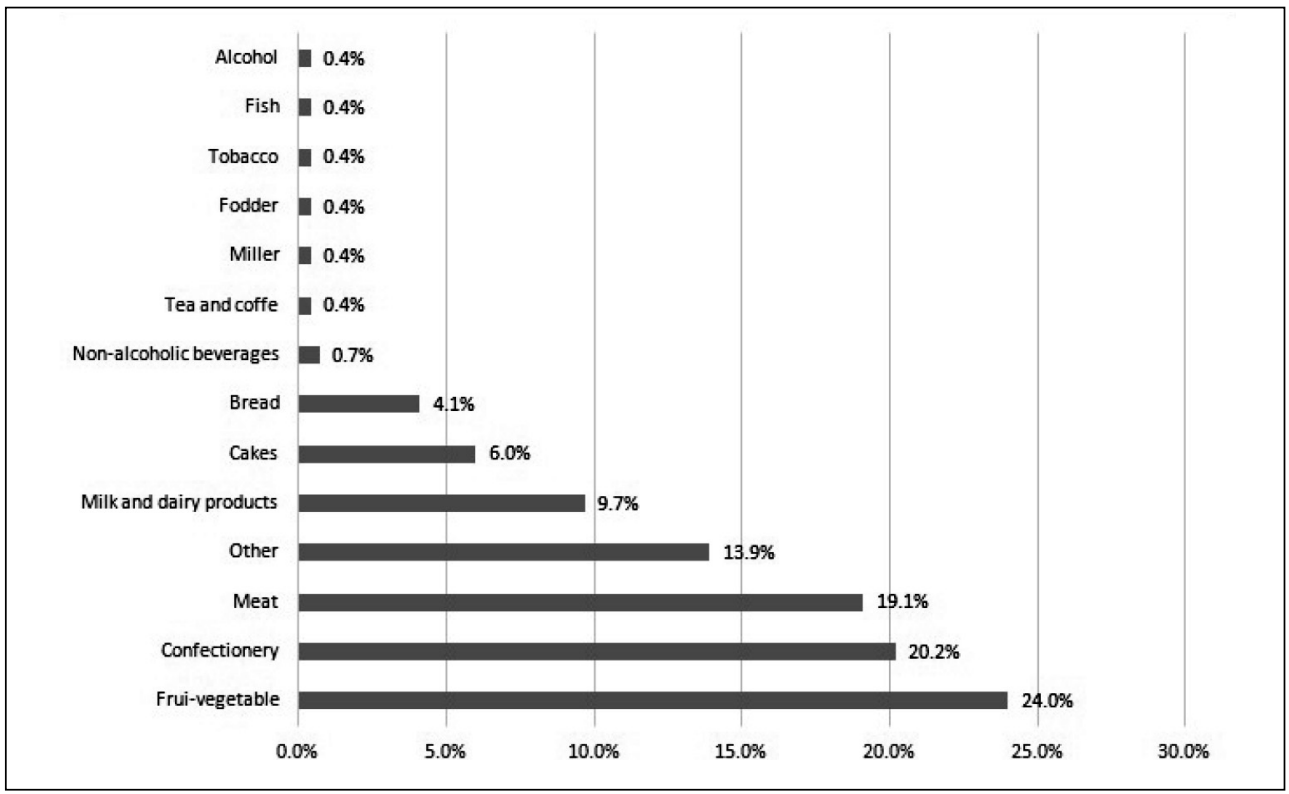

Source: own study based on research 
the current market conditions. Civil partnerships $(22.5 \%)$ and limited liability companies $(22.5 \%)$, and other legal forms, which were up to $20.6 \%$, were deemed as the most popular.

A joint stock company (15\%) and general partnership (13.1\%) as the average share in the types of legal forms. Cooperatives, which amount to $5.6 \%$ and limited partnerships $0.7 \%$ (Fig. 3) made up the smallest amounts. The following industries participated in this study: fruit and vegetables (24\%), confectionery $(20.2 \%)$, meat $(19.1 \%)$, dairy $(9.7 \%)$, pastry products $(6 \%)$, bakery $(4.1 \%)$, non-alcoholic beverages $(0.7 \%)$, coffee and tea processing $(0.4 \%)$, miller $(0.4 \%)$, fodder $(0.4 \%)$, tobacco $(0.4 \%)$, fish $(0.4 \%)$, alcohol $(0.4 \%)$ and other $(13.9 \%)$. The other group included companies that were not able to accurately determine their leading sector, as their activities related to the most two or more branches (Fig. 4).

Taking into account the criterion of the surveyed companies, it is clear that most of them are considered as medium (88\%) and large (12\%). Medium-sized enterprises are those that employ on average less than 250 full-time employees and have an annual turnover not exceeding EUR 50 million or an annual balance sheet total not exceeding EUR 43 million. Large enterprises are those that employ on average more than 250 full-time employees and an annual turnover exceeding EUR 50 million or an annual balance sheet total exceeding EUR 43 million.

\section{The Results of the Research in the Area of Knowledge Management in the Polish Food Industry}

In order to investigate the sources of knowledge, which the company can benefit from, as well as use in the current activities, they were initially selected in the external environment, where it was noted among new employees and acquired companies, strategic investors, as well as from benchmarking (Fig. 5). The statements of the respondents confirmed the possibility of obtaining knowledge from new employees. Based on our results, it was found that in food industry enterprises, sources of knowledge derived from new employees can be very useful (16.20\%) and useful (49.80\%). This shows the great interest of companies recruiting personnel, introducing new types of knowledge into the companies, which in the future may translate into generated profits. Nevertheless,
$1 / 3$ of the respondents considered these sources not very useful for the operation of companies $(27.30 \%)$ and $6.70 \%$ had no opinion on this subject. Sources of knowledge derived from the acquired companies were evaluated quite differently, as little more than a quarter of the respondents assessed them positively. They were assessed as very useful by $7.8 \%$ and useful by $19.9 \%$, but of little use by $54.3 \%$.

A relatively large group, as many as $18 \%$ of the respondents had no opinion on the subject. This behaviour is quite controversial in food businesses, as an innovative approach to mergers and acquisitions recommends even taking over companies along with their intellectual resources, which should be used to achieve the company's goals. The sources of knowledge derived from strategic investors have been assessed as very useful $(13.8 \%)$ and useful (31.5\%), which accounted for less than half of the respondents. As many as $54.7 \%$ of the respondents felt these sources are of little use $(41.2 \%)$ and $13.5 \%$ of them had no opinion on the matter.

One may question whether such a look at the sources of knowledge derived from the strategic investor is the preferred solution of the food business. The strategic investor, in addition to the acquisition of a significant stake in the company, should have significant influence on its management, which should significantly be supported by the possessed intellectual capital, know-how, skills and experience gained.

The strategic investor should even take care of the transfer of technical skills, conceptual, political and interpersonal skills to the company, on which they spend part of their resources. In practice, in the functioning of the food businesses in most cases, participation in the management of the company is limited to the transfer of a certain amount of financial resources and the withdrawal of the corresponding benefits. In taking benchmarks into consideration, food businesses see many opportunities in the development of this branch. Its part in the agri-food sector is a measurable definition of raw material purchase costs or savings in the production phase. Among the respondents, $6.7 \%$ of respondents considered its use to be "very useful", and $30 \%$ "useful". As many as $48.7 \%$ consider its use as being of little use, and $14.6 \%$ have had no opinion on this subject.

In further order, an attempt was made to assess the sources of used knowledge 


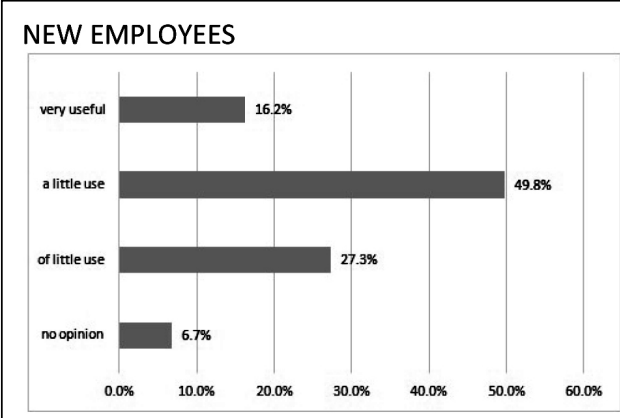

\section{STRATEGIC INVESTORS}

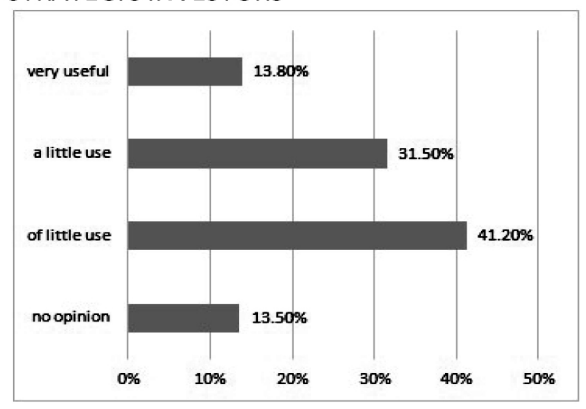

stemming from the cooperation with suppliers and customers (Fig. 6). The results of this study showed that the food business entrepreneurs highly appreciate any cooperation with them in this regard.

In the case of co-operation with suppliers, it was rated as very useful by $65.9 \%$ of the respondents, and in the case of cooperation with customers $-73.4 \%$, what clearly demonstrated that this is the highest form of cooperation among evaluated knowledge sources used. These sources were found useful by $28.5 \%$ of the respondents in the case of cooperation with suppliers, and $22.5 \%$ for cooperation with customers. Minute numbers referred to this form of cooperation as "not useful" (2.6\% and $2.6 \%$ respectively), and some did not have an opinion ( $3 \%$ and $1.5 \%)$.

Poorer results were obtained when testing companies regarding their collaboration with

\section{ACQUIRED COMPANIES}

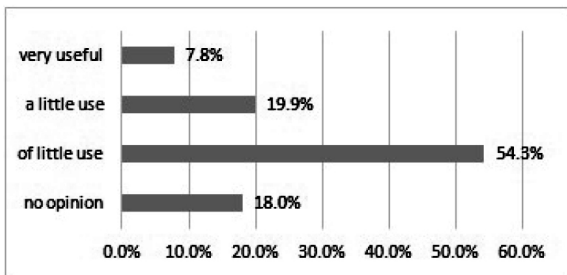

\section{BENCHMARKING}

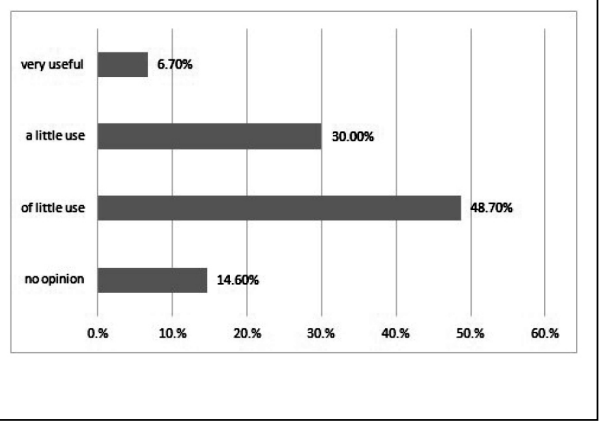

Source: own study based on research universities or research centres. Unfortunately this cooperation is not very popular among respondents, as only $2.5 \%$ considered it to be very useful for the current operation and development of enterprises and $15.4 \%$ as helpful.

As many as $65.2 \%$ considered this cooperation to be of little use, and $16.9 \%$ did not have their own opinion. Businesses, however, declared their willingness to cooperate in the implementation of projects, especially cofinanced by the European Union, with local governments, or the creation of university companies in order to commercialize the results of research and development (Fig. 7).

Similar results were obtained in evaluating cooperation by the enterprises with consulting companies, where only $4.4 \%$ of the respondents considered this to be very useful, and $25.5 \%$ as helpful. More than half of the respondents, as 


\section{Fig. 6: Sources of knowledge derived from suppliers, customers}

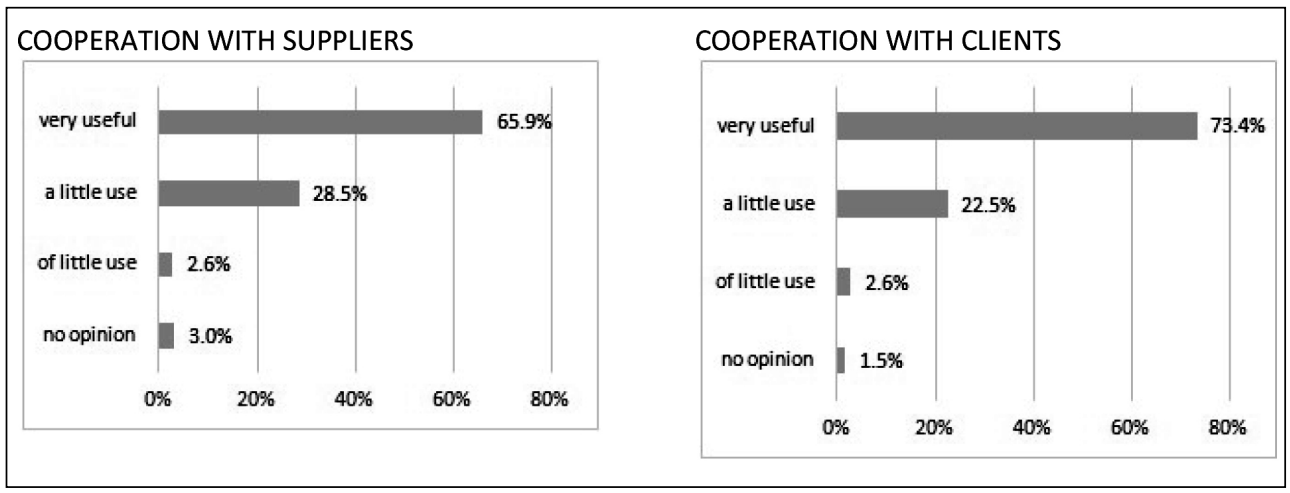

Source: own study based on research

many as $56.6 \%$ considered the cooperation to be of little use and $13.5 \%$ had no opinion on this subject. From the statements and opinions of respondents on this topic, it can be concluded that this kind of cooperation does not fully meet the needs of producers who frequently find their market insights to be sufficient for their needs. Respondents assessed the need for conducting market research in a different manner, as respondents in Poland generally view them as strengthening their information needs and esteem impacting the direction of the assortment production. Abroad, particularly in the United States, food and human nutrition has been the subject of many foresight studies, in which experts continually review trends in international trade in food and create development scenarios that are used in the establishing the company's production plans of the agri-food sector and companies engaged in the wholesale of food. Among the respondents, $33.4 \%$ rated the study as very useful, and $36.3 \%$ as useful, which represents almost $70 \%$ of respondents. The remaining respondents recognized market research as of little use for $24.3 \%$, and $6 \%$ had no opinion on this subject (Fig. 8).

Respondents were also asked to express their opinion on their own research and development department. Many of them

\section{Fig. 7: Sources of knowledge derived from cooperation with universities or research institutes and consulting companies}

\section{COOPERATION WITH UNIVERSITIES OR RESEARCH CENTRES}

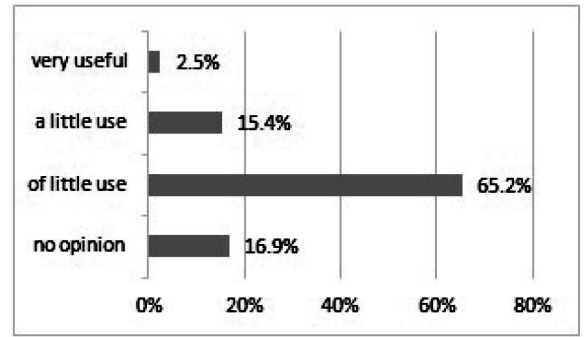

CONSULTING COMPANIES

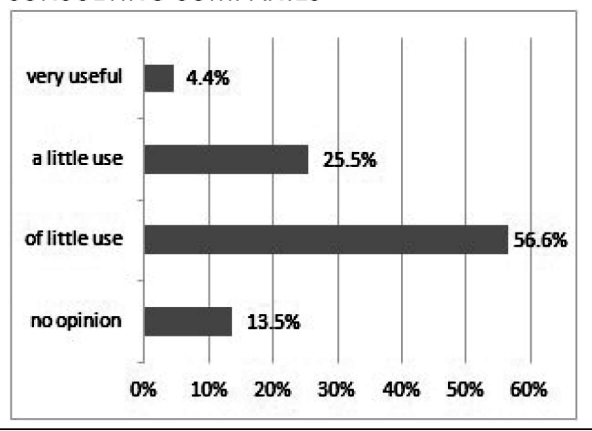

Source: own study based on research 


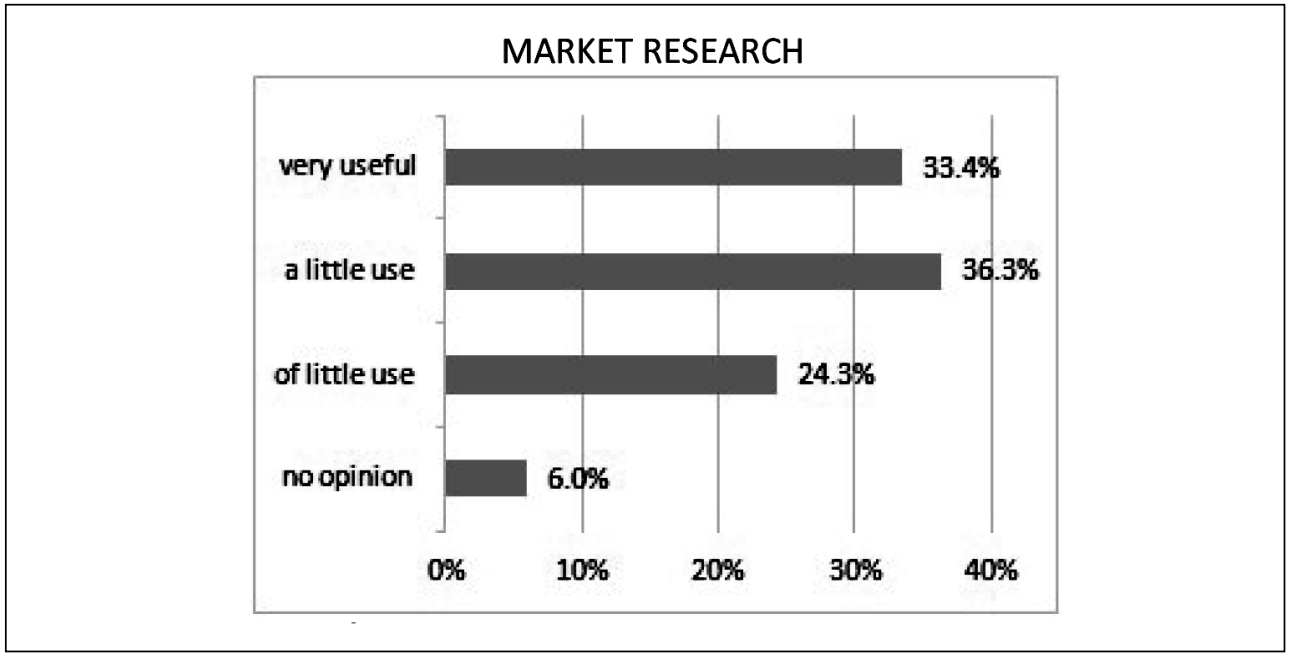

commented in a very positive manner on ensuring their companies a competitive position in the market with the professionalization of planning and management, as well as control and monitoring of the current research and development policy.

The R\&D departments create economically viable business plans or medium- and longterm development programs. Respondents evaluated their own research programs to support the improvement and modification of the existing range of food and developing all kinds of new technological, organisational aspects and production particularly well. More than half of them spoke favourably about the subject considering its function "very useful" $(21.7 \%)$ and "useful" (31.8\%). It was evaluated as being of little use by $34.1 \%$, and $12.4 \%$ had no opinion on this subject. External trainings were also very highly rated. More than three-quarters considered them to be "very useful" $(25.4 \%)$ and "useful" $50.6 \%$ ). It was rated as being of little help by $21 \%$, and $3 \%$ had no opinion on this subject. Employees of food companies consider external training to be supporting and expanding the existing skills and competencies, enabling the acquisition of new knowledge and sharing experiences with others in the food industry, which in the future will result in maximum orientation on the subject. They also made a charge of the lack of possibilities of immediate verifications of elements of knowledge gained during the trainings as well as their usability as specific job positions. Opinions were divided on congresses and industry meetings, because only $19.1 \%$ respondents recognized them as "very useful", and "useful" in $34.1 \%$ of the cases, which accounted for more than half of the respondents. Unfortunately, very few found them useful $-37.1 \%$, and $9.7 \%$ had no opinion on this subject. Respondents frequently pointed to the uselessness of repeated congress meeting topics and their cost. Industry meetings, which helped to understand the activities of competitive enterprises, and often establish cooperation, were assessed much higher. The usefulness of professional literature in the surveyed companies was evaluated similarly, and was rated as "very useful" by $16.5 \%$, and helpful in $30.7 \%$ of the cases, which is less than half of the surveyed companies. Unfortunately, the majority of the respondents did not find it useful enough $-43.1 \%$, and $9.7 \%$ had no opinion on this subject. Respondents indicated that the professional literature helps in keeping up with scientific and technological innovations, which, despite the wide availability, cannot be accessed through the Internet, and is often regarded as a less reliable source of information by serious enterprise (Fig. 9). 


\section{Sources of knowledge derived from their own research and development \\ Fig. 9: department, external training, conferences and business meetings and professional literature}

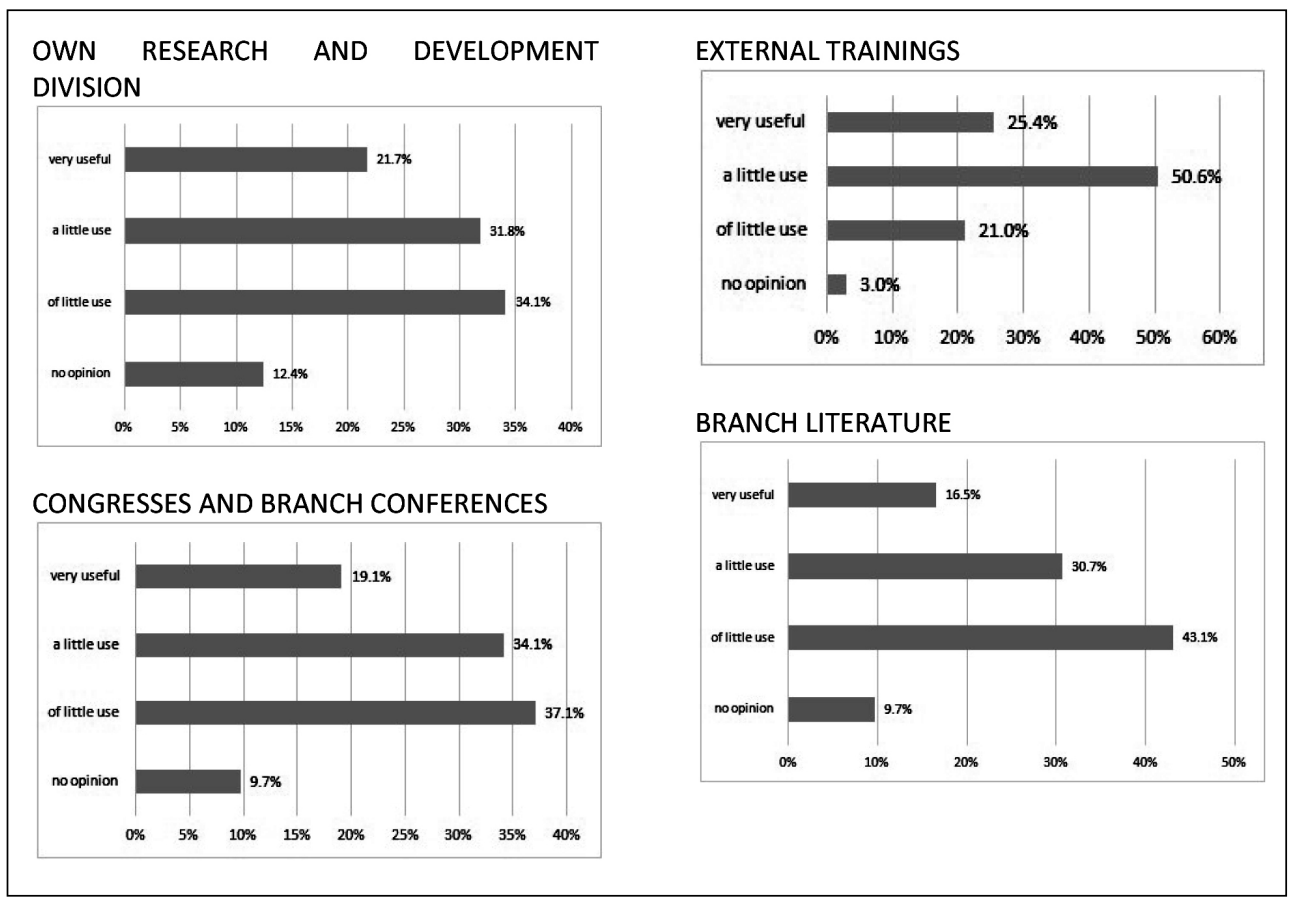

Source: own study based on research

In the present study, respondents were also asked to assess the use of systems and tools for storing information and internal communication within companies (Fig. 10). With a wide range, which was presented to respondents to choose from, they divided it into the most useful (answers in the range of $10-39 \%$ ), existing for the protection of the functioning of the enterprise (answers in the range 0-9\%) and support (answers in the range of $40-100 \%$ ). The Internet $(91 \%)$, e-mail (82\%) and workflow systems $(47 \%)$, with the highest scores of the proposed communication tools were among the most useful groups. The group of tools to protect the current functioning of the company included: data warehousing (23\%), software for group work (17\%), management support systems $(15 \%)$, teleconferencing $(14 \%)$ and systems, customer relationship management $(12 \%)$. Respondents considered Intranet $(8 \%)$, video conferencing $(5 \%)$ and other $(3 \%)$ as assisting tools.
In order to determine the average level of funding, we requested they be specified in each test year by the companies that spent them. The analysis found that throughout the period considered, with the exception of 2010 , their amount increased which may indicate a growing interest in them and understanding the benefits of this type of activity (Fig. 11).

On the other hand, Fig. 12 presents the percentage of respondents declaring that the food industry will benefit from funding for knowledge management. It can generally be said that the company applying these investments generally achieved better economic results in relation to the earlier ones $(64.4 \%)$, increased turnover (by $63.3 \%$ ), the value of sales $(59.2 \%)$ and expanded markets (49.8\%). In addition, respondents pointed to many other benefits derived from the application of knowledge management components, which was reflected by an increase in the total economic value of the company and their position on the market. 


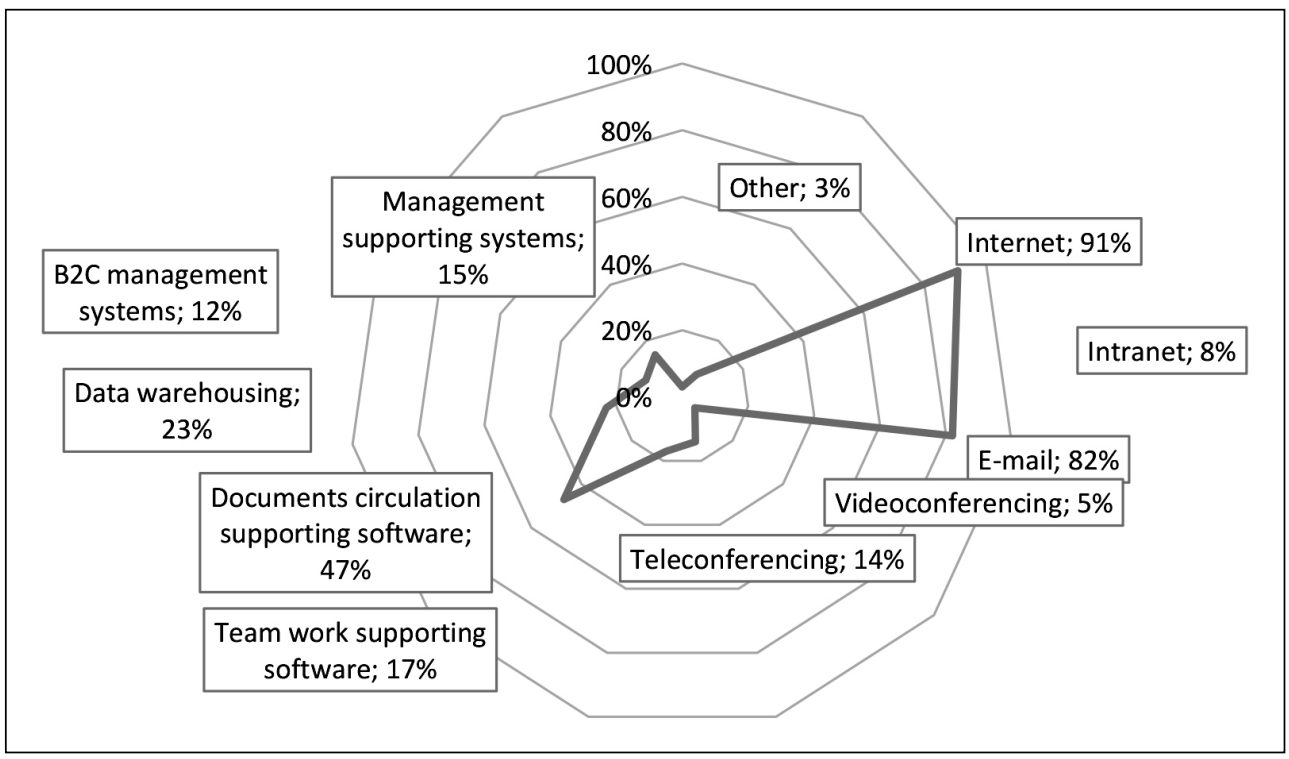

Source: own study based on research

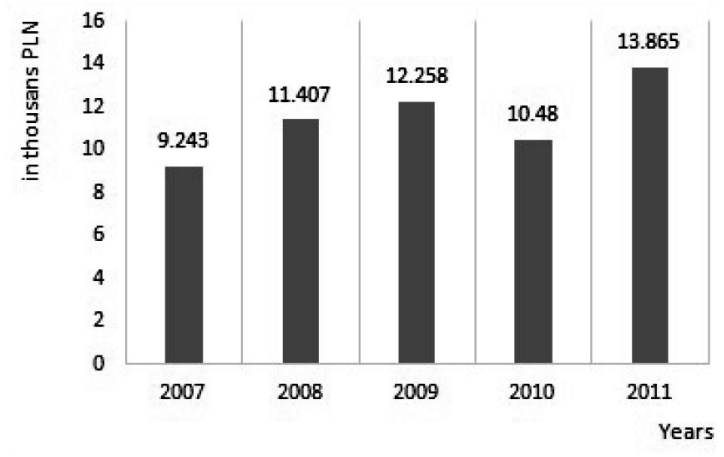

Source: own study based on research 


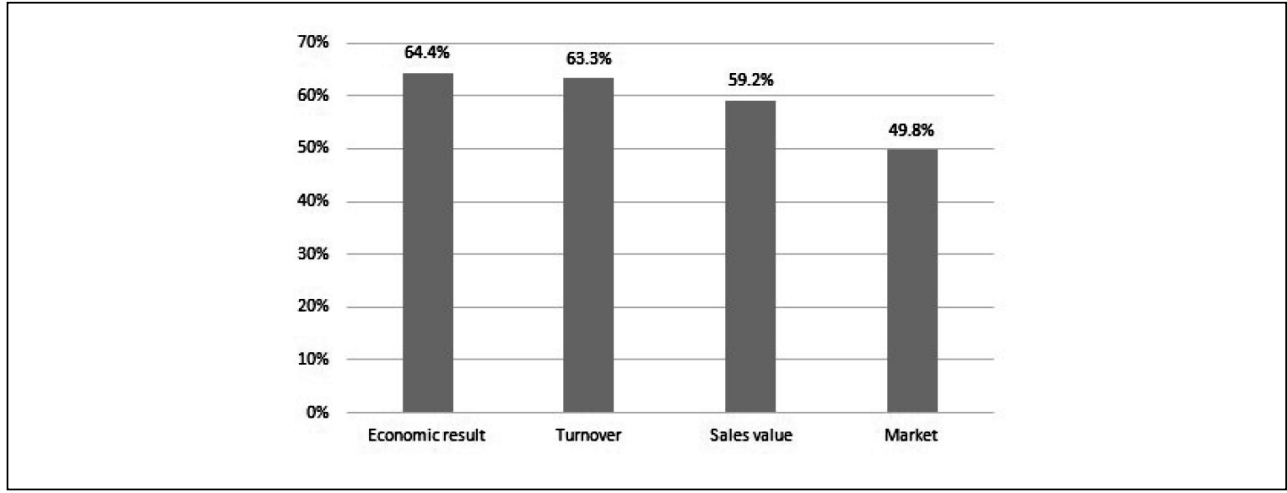

Source: own study based on research

\section{Conclusions}

The analysis of the issue of knowledge management in the food industry in Poland was conducted on the basis on the results of studies, which were to verify the thesis as to whether the food industry could be considered as sector implementing knowledge management components in 2007-2013. The evolution of the food industry in Poland was presented, its factual material as agribusiness made with the conducted economic analysis, organisational and financial analysis (research described in a separate paper) have shown that entrepreneurs running businesses in the food industry are actively engaged in exploring the full instrumentation including elements of knowledge management, tools and all kinds of sources of cooperation. The results of this study demonstrated that food business operators use various sources of knowledge. The collaboration that takes place between customers and suppliers, as well as external training was deemed as most significant. The lack of interest in the surveyed enterprises in using the knowledge of the acquired business is interesting, and very minimal cooperation with universities or research centres is surprising. This follows from the fact that companies frequently acquire knowledge in trade relations, but also from specialist companies equipped with a suitable base, which also were considered as the most useful. The lack of cooperation with universities and research centres can attest to the impossibility of its use in practical applications in enterprises, or a lack of understanding of the benefits of this kind of cooperation. The study and the results led to the following conclusions:

1. Unfortunately, only less than $2 / 3$ of the surveyed enterprises of the food industry carried out activities related to the implementation of elements of knowledge management in the company in the years 2007-2012. This underlines the small interest in this type of action resulting from the lack of profitability or having to incur high costs in relation to the obtained results. The lack of a conscious approach to strategic planning and treating it as a long-term and formal process aimed at achieving these goals could also have been an obstacle. Companies that implement elements of knowledge management, most often pursue training, showed knowledge management as a system of motivation, as well as make use of all kinds of forms of guidance.

2. Internal training proved to be one of the most supportive measures of implemented acquisition and knowledge transfer. Mentoring also relies on the care of experienced staff on junior staff as well as a staff rotation system was used for the positions. Businesses were most interested in the use of practical knowledge, but also the Internet, electronic mail (e-mail), document circulation systems and data warehouses. 
3. The results of the study indicated that in 2007, more than half of the surveyed enterprises of the food industry spent funds for knowledge management, increasing them annually. In 2011 , the percentage of companies disbursing them was less than $2 / 3$. The disbursement of funds contributed to the improvement of the economic performance of enterprises, increase in the turnover of the company, as well as the expansion of markets.

4. In the surveyed enterprises the average level of financial resources incurred for knowledge management in the years 20072011 increased annually (except for 2010). These measures increased from PLN 9,243.37 in 2007 to PLN 13,865.01 in 2011. There has also been a growing proportion of the surveyed companies, which declared the increase in value as well as the size of the selected characteristics of their business, which has risen as a result of incurring financial outlays for knowledge management.

The project was financed from the funds of the National Centre for Science in Poland, Grant no. 2011/01/B/HS4/06302

\section{References}

Firlej, K. (2008). Zarządzanie wiedzą warunkiem rozwoju przedsiębiorstw przemysłu spożywczego. In A. Glińska-Neweś (Ed.), Zarządzanie organisacjami $w$ gospodarce opartej na wiedzy. Zasobowe podstawy funkcjonowania i rozwoju organisacji (pp. 121133). Toruń: Uniwersytet Mikołaja Kopernika w Toruniu i Towarzystwo Naukowe Organisacji i Kierownictwa, Oddział Toruń.

Firlej, K. (2010). Globalizacja i integracja europejska - szansa czy mit dla polskiego agrobiznesu. In Ekonomika $i$ organisacja gospodarki żywnościowej, „Zeszyty Naukowe Szkoły Głównej Gospodarstwa Wiejskiego w Warszawie" nr 84 (pp. 23-32). Warszawa: Wydawnictwo SGGW.

Firlej, K. (2012). Knowledge Management and Diffusion of Innovations In the Process of Restructuring Agriculture and Food Industry Companies. In Knowledge Management and Diffusion of Innovations In the Process of Restructuring Agriculture and Food Industry Companies (pp. 83-93). Ostrołęka: Wydawnictwo Wyższej Szkoły EkonomicznoSpołecznej w Ostrołęce.
Firlej, K., \& Rydz, A. (2012). Operation Conditions of Food Businesses In the Knowledge-Based Economy. In Human Resource Management and Corporate Competitiveness (pp. 151-162). Godolo: Szent Istvan University Publishing.

Firlej, K., \& Rydz, A. (2012). System doradztwa rolniczego w Polsce oraz jego wykorzystanie w ramach działania 114 PROW 2007-2013. In A. Czyżewski (Ed.), Roczniki Ekonomiczne Kujawsko-Pomorskiej Szkoły Wyższej w Bydgoszczy, No. 5 (pp. 199-222). Bydgoszcz: Wydawnictwo KujawskoPomorskiej Szkoły Wyższej w Bydgoszczy.

Firlej, K., \& Żmija, D. (2014). Transfer wiedzy i dyfuzja innowacji jako źródło konkurencyjności przedsiębiorstw przemysłu spożywczego w Polsce (pp. 8-13). Kraków: Fundacja Uniwersytetu Ekonomicznego w Krakowie.

Gach, D. (2008). Pozyskiwanie i wykorzystanie wiedzy klientów. E-mentor, 23(1), 57-60.

Pierścionek, Z., \& Jurek-Stęń, S. (2006). Czynniki sukcesu polskich przedsiębiorstw na rynkach Unii Europejskiej (pp. 9-13). Warszawa: Szkoła Główna Handlowa w Warszawie.

Słownik Współczesnego Języka Polskiego. (1996). Warszawa: Wilga.

Sopińska, A. (2006). Rozwój gospodarki wiedzy (GOW) w Polsce. In M. Trocki, \& S. Gregorczyk (Eds.), Nowoczesne zarządzanie. Koncepcje $i$ instrument (pp. 165). Warszawa: Szkoła Główna Handlowa w Warszawie.

Szreder, M. (2004). Metody i techniki sondażowych badań opinii (pp. 120). Warszawa: Polskie Wydawnictwo Ekonomiczne.

Urban, R. (2010). Przyspieszenie rozwoju polskiego przemysłu spożywczego. In R. Urban, R. Mroczek, \& I. Szczepaniak (Eds.), Polski sektor żywnościowy w pierwszych latach członkostwa (Synteza), nr 177 (pp. 29), Warszawa: IERiGŻ-PIB.

Prof. nadzw. dr hab. Krzysztof Firlej, Assoc. Prof. PhD Cracow University of Economics Department of Strategy Management and Organisation Development krzysztof.firlej@uek.krakow.pl

dr hab. Dariusz Żmija, Assist. Prof., PhD Cracow University of Economics Department of Economic Policy and Development Programming zmijad@uek.krakow.pl 


\title{
Abstract
}

\section{THE SPECIFICITY OF KNOWLEDGE MANAGEMENT INTHE FOOD INDUSTRY IN POLAND}

\author{
Krzysztof Firlej, Dariusz Żmija
}

The article presents an analysis of the problems of knowledge management in the food industry in Poland, which was carried out on the basis of the results of the author's own study. The study was conducted in the years 2007-2013. The research shows that businesses established in the food industry are actively involved in the use of knowledge management instruments including: elements, tools and all kinds of sources of cooperation. The company's production processes use various sources of knowledge. It should be noted that outstanding cooperation takes place between customers and suppliers, as well as in external training. A weak interest of the surveyed enterprises in using the knowledge of the acquired business, and very insignificant cooperation with universities or research centres was discovered. Companies frequently acquire knowledge in trade relations, but also from specialist companies with an appropriate base which was also recognized as the most useful sources. The lack of cooperation with universities and research centres can attest to the impossibility of its use in practical applications in enterprises, or a lack of understanding of the benefits of this kind of cooperation. It is stated that, in the years 2007-2012, less than 2/3 of the surveyed enterprises of the food industry carried out activities related to the implementation of elements of knowledge management in the enterprise; internal training proved to be the most supportive in implementing acquisition and transfer of knowledge; more than half of the surveyed enterprises of the food industry spend funds on knowledge management, increasing them annually; surveyed companies noted the annual increase in the average level of financial resources incurred for the management of knowledge in the years 2007-2011(except 2010).

Key Words: Knowledge management, food industry, intellectual capital.

JEL Classification: D2, L2, L6.

DOI: 10.15240/tul/001/2017-1-006 